\title{
Estimating Above-Ground Biomass of Araucaria angustifolia (Bertol.) Kuntze Using LiDAR Data
}

\author{
Franciel Eduardo $\operatorname{Rex}^{1}\left(\mathbb{D}\right.$, Ana Paula Dalla Corte ${ }^{1}$ (D), \\ Sebastião do Amaral Machado ${ }^{1}$ (D), Carlos Alberto Silva ${ }^{2}$ (D), \\ Carlos Roberto Sanquetta ${ }^{1}$ \\ ${ }^{1}$ Universidade Federal do Paraná (UFPR), Paraná, PR, Brasil \\ ${ }^{2}$ University of Maryland, College Park, MD, USA
}

\begin{abstract}
The objective of this study was to test the performance of canopy data obtained from Airborne Laser Scanner (ALS) in generating estimates of above-ground biomass (AGB) of Araucaria angustifolia (Bertol.) Kuntze individuals. A cloud of ALS points located in a fragment of native urban forest in Curitiba, Paraná was used. The procedures consisted of: classifying points; obtaining and smoothing the Canopy Height Model (CHM); detecting peaks and segmenting canopy using eCognition software. Mathematical models were adjusted to estimate the AGB from the crown areas. Two equations were required to estimate the individual AGB, while $\mathrm{R}^{2}(\%)$ values of 96.19 and 98.89 were found. The total AGB stock found was $264.333 \mathrm{~kg}$. The LiDAR technology and the methods for obtaining the information used in this work constitute non-destructive and precise tools for quantifying biomass in native forests.
\end{abstract}

Keywords: native forest, estimation equations, remote sensing. 


\section{INTRODUCTION AND OBJECTIVES}

Forests play a key role in the forest carbon cycle (IPCC, 2006, 2010). It is estimated that they store about 283 gigatonnes (Gt) of carbon (FAO, 2010), which when added to the carbon stored in the necromass, litterfall and soil correspond to a higher carbon concentration than that present in the atmosphere (Solomon et al., 2007).

The above-ground biomass (AGB) estimated on a landscape scale presents an important measure to understand and explain the atmospheric carbon balance (Anaya et al., 2009; Hall et al., 2011; Houghton et al., 2009; Hudak et al., 2012; Li et al., 2010; Lu, 2006; Tangki \& Chappell, 2008). Many studies have produced regional or global AGB estimates using a combination of field data and remote sensing. In order to make these estimates feasible, it is necessary that field data relate to the existing biomass/carbon stocks in the field and the variables collected by remote sensors.

Forest biomass can be obtained by direct methods which involve felling and weighing all the arboreal plant material, or by indirect methods involving the use of allometric equations, satellite images (Silva et al., 2015) or artificial intelligence (Schoeninger et al., 2009) and expansion factors (Silveira, 2010). Field data collection is extremely time consuming and expensive (Chave et al., 2014). On the other hand, indirect methods consist of using allometric models which relate biomass or carbon (difficult variables to obtain), with commonly measured variables (tree diameter and height) in the field in forest inventory work (Sanquetta et al., 2014; Schikowski et al., 2013).

Despite the growing scientific advancement in AGB quantification, some types of forests, such as the Atlantic Forest, have few studies that model their biomass using remote sensing methods (Freitas et al., 2005). In addition, this is a biome of great territorial extension, which contains many areas of difficult access with accented slopes (Munroe et al., 2007; Southworth \& Tucker, 2001, Teixeira et al., 2009), making it even more difficult to determine AGB by the destructive method (Lu, 2006). Thus, techniques which enable estimating biomass in an automated way such as by remote sensing should be more deeply researched (He et al., 2012; Soenen et al., 2010; Sun et al., 2002).
Remote sensing is an important tool that can support estimating and monitoring forest resources (Turner et al., 2003; Zolkos et al., 2013), as well as the distribution of AGB on a large scale (Gao, 2007). However, the use of advanced instruments is necessary in order to provide useful fine scale data for environmental management purposes (Corona, 2016). It is possible to highlight the Airborne Laser Scanner system (ALS), based on Light Detection and Ranging (LiDAR) technology, which obtains direct measurements of vegetation through an airborne platform (Dubayah et al., 2000; Popescu et al., 2011). This system is the most used to obtain phytostructural parameters because it is easy to use and provides accurate results (Anderson et al., 2006; Dean et al., 2009; Roberts et al., 2005).

Thus, the use of this sensor is indicated for estimating forest biomass, since the variables that can be directly measured by LiDAR correlate with the AGB data measured in the field (Drake et al., 2003). However, it is important to note that no remote sensing instrument can provide direct biomass measurements, so that direct field measurements are required to establish relationships between remote sensing and biomass signals to estimate AGB on large scales (Rosenqvist et al., 2003).

In view of the above, the present study had the objective to test the approach based on airborne LiDAR for quantifying the AGB of $A$. angustifolia individuals in a native forest fragment of the Atlantic Forest. The specific objectives of the study were: (1) to test the performance of LiDAR data for detecting canopies of A. angustifolia individuals; and (2) to apply a model to estimate AGB of the same individuals.

\section{MATERIALS AND METHODS}

\subsection{Field study and inventory area}

The study area comprises a mixed Ombrophilous forest (MOF) fragment located in Curitiba, Paraná (PR), between the coordinates $25^{\circ} 26^{\prime} 50^{\prime \prime}$ and $25^{\circ} 27^{\prime} 33^{\prime \prime}$ $\mathrm{S}$ and $49^{\circ} 14^{\prime} 16^{\prime \prime}$ and $49^{\circ} 14^{\prime} 33^{\prime \prime} \mathrm{W}$, at approximately $900 \mathrm{~m}$ altitude (Machado et al., 2012). The climate is classified as subtropical humid mesothermal (Cfb) with undefined dry season, with average temperature in the hottest month of $22^{\circ} \mathrm{C}$ and $12^{\circ} \mathrm{C}$ in the coldest month (Peel et al., 2007). 
A forest census was carried out in the study area in the year 2015. The area was divided into blocks of $50 \mathrm{~m} \times 50 \mathrm{~m}$, which were georeferenced from the north on a map of the region and materialized in the field with the use of a theodolite. All individuals with diameter at breast height (DBH, $1.30 \mathrm{~m}$ ) above $10 \mathrm{~cm}$ were measured, identified, recorded and georeferenced from the apex of each block, as described by Machado et al. (2009) and Machado et al. (2010). Only individuals of the A. angustifolia species were selected for this study, and they all had their coordinates determined in the field using a Garmin GPS 62CSX.

\subsection{Airborne LiDAR data collection}

Airborne LiDAR data were collected in 2012 and a high resolution orthorectified aerial image of the same area was obtained. The main characteristics of the collected data are: LiDAR point cloud with average point density of 4 points. $\mathrm{m}^{-2}$; altimetric accuracy of $10 \mathrm{~cm}$; orthoimage ground sampling distance (GSD) of $18 \mathrm{~cm}$; and scale of 1:2,000.

\subsection{Basic processing of the LiDAR point cloud}

Prior to basic cloud processing, the LiDAR data organization and preparation of the M-DOS environment was performed on the Windows system. The process was divided into two steps: basic ALS cloud processing and digital processing of the models. The former was processed using Lastools v.111216 software (Isenburg, 2014), while the latter was carried out using ArcGIS 10.4 software. Figure 1 illustrates the flowchart of the main processing steps.

The first processing corresponded to classifying the soil and surface points in order to obtain the digital terrain model (DTM) and the digital surface model (DSM). After obtaining them, a subtraction was performed among models to obtain the canopy height model (CHM). This was performed using the raster calculator tool available in the ArcGIS 10.4 software program.

Next, the CHM underwent a series of smoothing filters for noise reduction, a step that is essential in studies of automatic canopy identification for extracting information (Suárez et al., 2005). Search windows, which are matrices of pixels with variable size, were used to find the highest value referring to the tops of the trees using the raster calculator and focal statistics tools. The input image corresponded to the CHM and the output to a smoothed CHM image $(s \mathrm{CHM})$ with only pixels of the points referring to the treetops, which was converted to a point shapefile. In summary, mean and minimum filters were used at this stage, as well as corrections to verify whether the image pixel had a lower value than its counterpart in the CHM image.
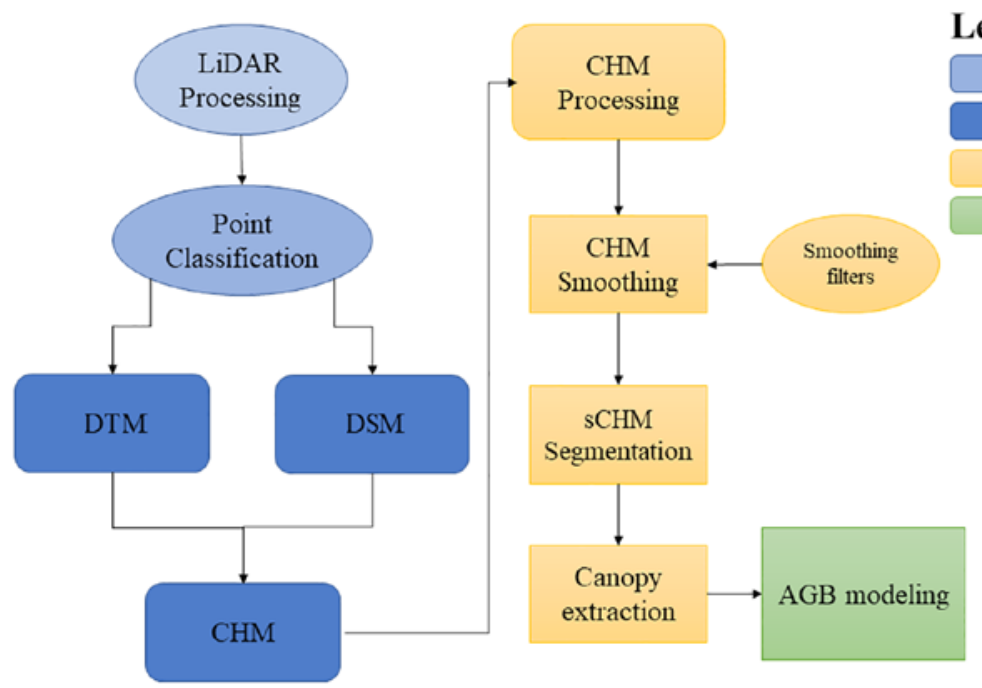

\section{Legend}

LiDAR Processing
LiDAR Products
CHM Processing
Final Product

LiDAR Processing

CHM Processing

Figure 1. Flowchart of the main data processing stages. DTM: digital terrain model; DSM: digital surface model; CHM: canopy height model; sCHM: smooth canopy height model; AGB: above-ground biomass. 


\subsection{Segmentation of A. angustifolia individuals}

Segmentation of $A$. angustifolia individuals was performed using the algorithm by region growth implemented in the eCognition software, which has an object-oriented approach as its main characteristic. According to Mitri \& Gitas (2004), the object-oriented classification was developed to overcome the limitations of traditional methods for extracting information when using high spatial resolution.

Some intervals were tested for delimiting tree canopies in the segmentation process, namely Scale Parameter (SP 15 to 20; amplitude of 1), while the default values of the software were used (0.1 and 0.5 ) for other parameters (shape and compactness). After the segmentation procedure, the vector file was imported into the ArcGis 10.4 software and filtered in order to leave only the A. angustifolia canopies. As the occurrence points of the individuals in the field were known, the values corresponding to the area in square meters $\left(\mathrm{m}^{2}\right)$ of each canopy were then extracted.

Regarding the orthorectified image, a visual interpretation of $A$. angustifolia crowns present in the area was performed, with the purpose of serving as controls for the present study. To do so, the location points of trees collected in the field with the GPS were used and the on-screen interpretation was performed in the ArcGIS 10.4 software.

\subsection{AGB modeling of A. angustifolia individuals}

The objective of this study was to test the biomass expression as a function of the crown area $\left(\mathrm{m}^{2}\right)$. Thus, the database of a direct biomass quantification by Watzlawick (2003) in a MOF was used to develop the mathematical model that expressed this relation. All A. angustifolia individuals to be used in the present study were selected from this database. Next, the equation developed by Sanquetta et al. (2011) was used for estimating crown areas of these individuals, in which measurements were taken from a MOF fragment with a sampling of $47 \mathrm{~A}$. angustifolia trees with the projection of at least four canopy rays per tree. The result is presented in Equation 1:

$$
C A=35.6111+2.0132(d b h)+-0.005\left(d b h^{2}\right)
$$

Coefficient of determination $\left(\mathrm{R}^{2}\right)$ : 0.77.; $\mathrm{S}_{\mathrm{yx}} \%=47.7 \%$. CA: crown area $\left(\mathrm{m}^{2}\right)$; dbh: diameter at $1.30 \mathrm{~m}$ height $(\mathrm{cm})$.
In other words, dbh data from the database of Watzlawick (2003) were used to estimate crown areas using the equation developed by Sanquetta et al. (2011). The biomass model was then expressed as a function of crown area $\left(\mathrm{m}^{2}\right)$ of A. angustifolia individuals.

After that, the model for estimating AGB was developed based on the crown areas of the individuals. The accuracy of the model was evaluated by $\mathrm{R}^{2}$, rootmean-square error (RMSE) and BIAS, according to Equations 2 and 3.

$R M S E=\sqrt{\frac{\sum_{i=1}^{n}\left(y_{i}-\widehat{y}_{i}\right)^{2}}{n}}$

$B I A S=\frac{1}{n} \sum_{i=1}^{n}\left(y_{i}-\widehat{y}_{i}\right)$

$n$ : number of $A$. angustifolia individuals; $y_{i}$ : observed value of above-ground biomass $(\mathrm{kg}) ; i$ and $\widehat{y}_{i}$ : predicted value of above-ground biomass $(\mathrm{kg}) i$.

Three treatments were defined $(\mathrm{T} 1=$ Control, $\mathrm{T} 2$ $=$ Automatic Classification and T3 = Semi-automatic Classification) to evaluate the results. T1 refers to the census used as the basis for this work, meaning the inventory at $100 \%$ of A. angustifolia, totaling 336 individuals. T2 refers to the correctly identified crowns, which represents the correctness of the classifier without manual intervention; and $\mathrm{T} 3$ represents the canopies that the classifier did not identify, requiring manual intervention by the photo interpreter.

\section{RESULTS}

The products generated by processing the LiDAR cloud were the DTM, which varied in altitude from $890.5 \mathrm{~m}$ to $922.7 \mathrm{~m}$, and the DSM from $894.8 \mathrm{~m}$ to $937.9 \mathrm{~m}$. The CHM is a byproduct of these models and the one which enables the obtention of the tree heights. This model presented a value of $32.79 \mathrm{~m}$, being the value of the largest tree present in the area. The image was highlighted with the smoothing filters applied in the CHM, leaving the tree tops softer so that the segmentation process was optimized. Applying the filters promoted smoothing of the maximum peaks and reducing the altitude of the $\mathrm{CHM}$, for which its application had a maximum value of $26.5 \mathrm{~m}$ (Figure 2). 

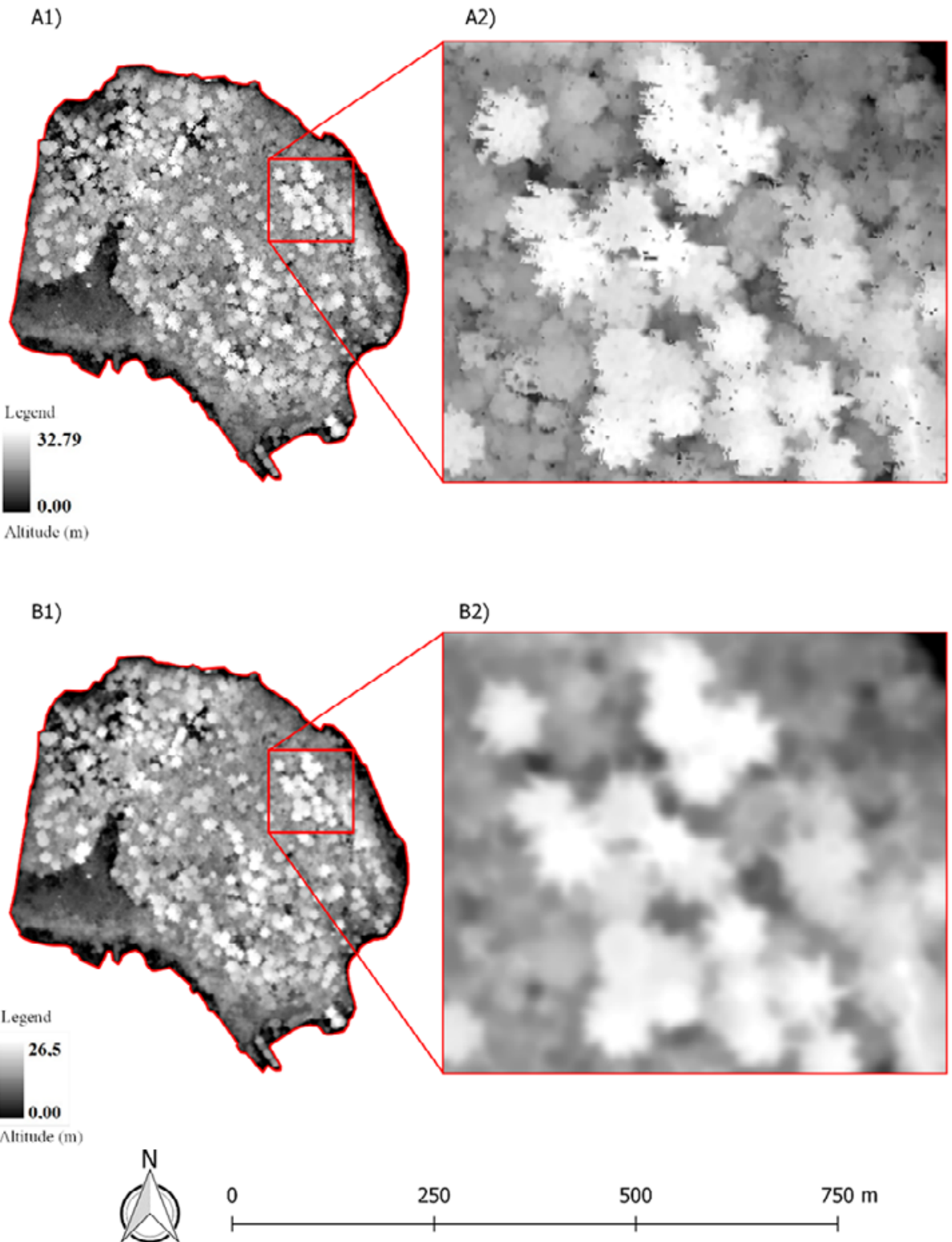

Figure 2. A1) Canopy Height Model (CHM); A2) CHM with zoom focusing on areas with A. angustifolia canopy; B1) Smooth Canopy Height Model (sCHM); B2) sCHM with zoom focusing on areas with A. angustifolia canopy.

Application of smoothing filters generally allowed removal of image noise, as well as reducing the likelihood of trees being falsely identified. In the segmentation process, the value for the scaling parameter that provided the best result was 18 , while 382 polygons were obtained as the result of the CHM segmentation, and they correspond to the canopies of A. angustifolia individuals. This value was found due to the classifier targeting a single canopy in multiple regions.
Some adjustments were necessary based on the result of the overlapping segmentation in the orthophoto, mainly the exclusion of polygons that the software could not homogenize as a single canopy. After the filters were applied (exclusion and adjustment of the polygons) to the canopies, 297 crowns were identified and extracted automatically (T2), meaning that $\mathrm{T} 2$ correctly identified $88.4 \%$ in relation to the control (T1). On the other hand, $90.8 \%$ were correctly identified 
in T3 in delimiting the crowns, as 305 crowns were identified in this process which corresponds to the sum of the result of T2 (297 crowns), in addition to the eight crowns from the semi-automatic classification (T3). Figure 3 shows the segmentation result of the crowns of the tested classifiers.

Summarizing, 297 individuals of $A$. angustifolia (polygons delimited in white) were automatically classified (T2). However, eight trees (in black) were identified using only the semi-automatic classification (T3), despite being the target species. In this sense, by adding the result of the T3 (eight trees) with the 297 individuals of the T2, we have a total of 305 individuals identified with the present methodology, which represents a final agreement of $90.8 \%$ in relation to the census of 336 A. angustifolia individuals.

A. angustifolia individuals were easily identified in the image. The process of obtaining the crowns automatically was also efficient. In addition, it is important to note that the use of GPS navigation in this process did not interfere with the methodology used to identify the individuals in the image, since this instrument was used to ensure the veracity of the information.

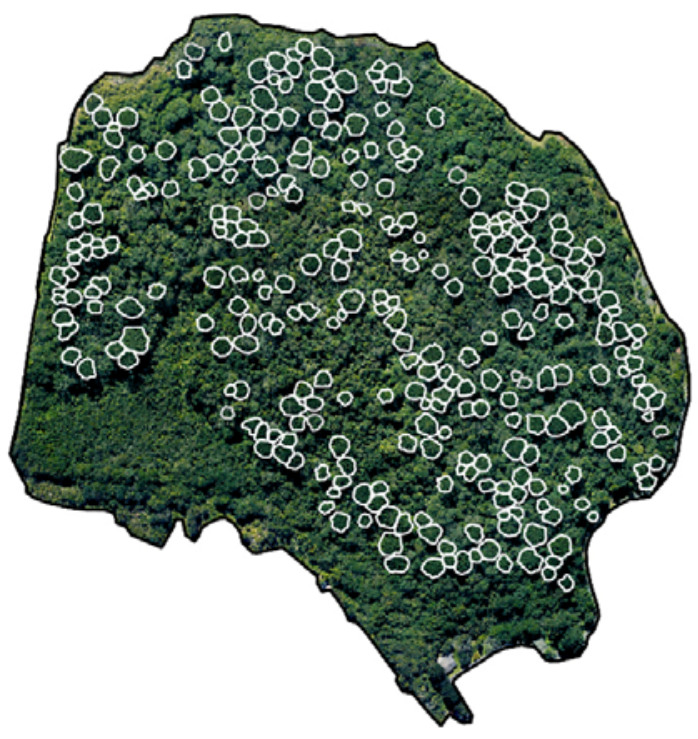

Legend

Final Canopies
The crown area (CA) values of $A$. angustifolia individuals presented a mean of $107.22 \mathrm{~m}^{2} \pm 45.12 \mathrm{~m}^{2}$ and of $108.44 \mathrm{~m}^{2} \pm 45.41 \mathrm{~m}^{2}$, respectively for the semiautomatic (T3) and automatic classifications (T2). The minimum and maximum CA values were $26.17 \mathrm{~m}^{2}$ and $290.63 \mathrm{~m}^{2}$, respectively. Evaluating the distribution of the variable in question (Figure 4), it can be seen that both treatments (T2 and T3) present a high concentration of individuals with values close to the observed means $\left(107.22 \mathrm{~m}^{2}\right.$ and $\left.108.44 \mathrm{~m}^{2}\right)$. The presence of a peak near the final CA classes $\left(180 \mathrm{~m}^{2}-200 \mathrm{~m}^{2}\right)$ was also observed, indicating a bimodality pattern.

In relation to the identified individuals, the LiDAR technology is very efficient, especially when associated with other tools such as object-oriented classification (segmentation). Through the implemented methodology, it was possible to delimit about $90.8 \%$ of the individuals. Considering that the census of the area listed a total of 336 A. angustifolia individuals, there is a high percentage of identification, especially because the species occurs among others in a natural ecosystem. There are few works developed in native forests in this context, mainly due to the complexity of the environment and the various ecological interferences it suffers.

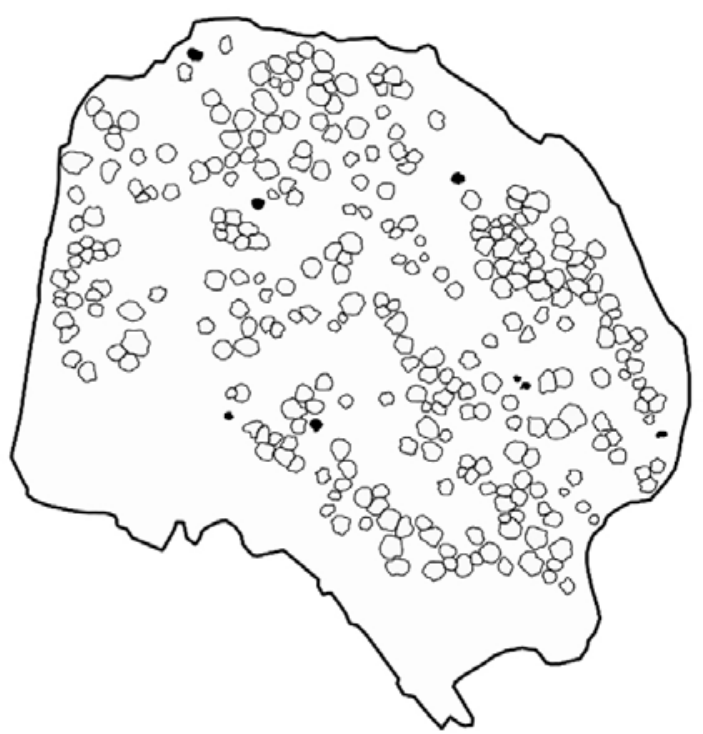

Legend

Semiautomatic Classification Automatic Classification

Figure 3. Digital orthoimagery of the area with the best segmentation result after adjustment and exclusion of deflection polygons and visual identification of the canopies not extracted by the segmentation process. 

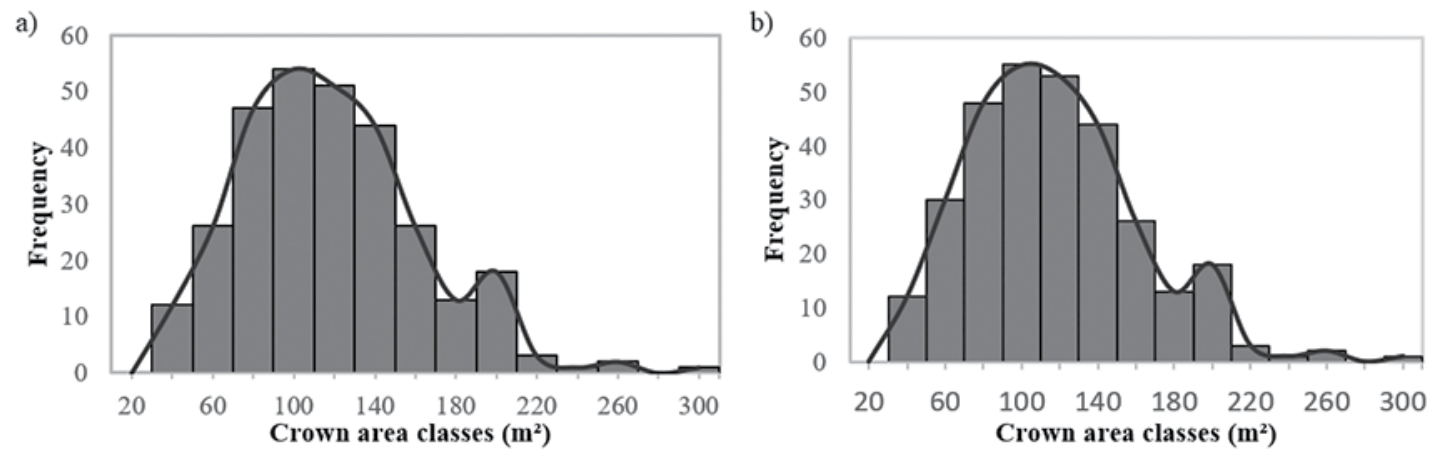

Figure 4. Frequency histogram for the crown area of A. angustifolia individuals. a) Automatic classification; b) Semiautomatic analysis.

The development of two equations were necessary for AGB estimation due to the great variation of crown areas found and to the distinct behavior of this variable as a function of the size of individuals. With the use of these, it was possible to better represent the AGB as a function of the crown area. Equation 4 was developed and applied to crown areas smaller than $183 \mathrm{~m}^{2}$, while Equation 5 was applied to crown areas equal to or greater than $183 \mathrm{~m}^{2}$.

$$
A G B=5 E^{-05}(A C)^{3,4478}
$$

For $\mathrm{CA}<183 \mathrm{~m}^{2}$.

AGB: above-ground biomass ( $\mathrm{kg})$; CA: crown area $\left(\mathrm{m}^{2}\right)$.

$$
A G B=0.13512 * C A^{2}-7.8836 * C A-63.487
$$

For $\mathrm{CA} \geq 183 \mathrm{~m}^{2}$.

AGB: above-ground biomass $(\mathrm{kg})$; CA: crown area $\left(\mathrm{m}^{2}\right)$.

The developed equations indicate good performance for estimating the AGB of A. angustifolia individuals, since the coefficient of determination $\left(R^{2}\right)$ values were 0.96 and 0.98 for Equations 4 and 5, respectively. The respective RMSE (\%) and BIAS (\%) values were 0.03 and 0.95 and 1.01 and -0.95 . In summary, the AGB estimated for A. angustifolia presents mean values ranging from $65.96 \mathrm{~kg}$ to $9,058.52 \mathrm{~kg}$ for the crown area classes. The total AGB stock in the entire study area (which is approximately 15 hectares) was $264.333 \mathrm{~kg}$ (Table 1).

The highest AGB value $(98.462 \mathrm{~kg})$ was found in the class of CA $126.15 \mathrm{~m}^{2}-176.15 \mathrm{~m}^{2}$, in which 65 A. angustifolia individuals were found. With only one individual, the CA class $276.17 \mathrm{~m}^{2}-326.17 \mathrm{~m}^{2}$ presented a total of $9,058 \mathrm{~kg}$ of biomass, representing about $3.42 \%$ of the estimated total area for these individuals. The largest number of individuals was found in the CA class of $76.17 \mathrm{~m}^{2}$ to $126.17 \mathrm{~m}^{2}$, with 136 trees whose biomass totals were $58.877 \mathrm{~kg}$, which is about $22 \%$ of the total. The class $26.17 \mathrm{~m}^{2}-76.17 \mathrm{~m}^{2}$, with 79 individuals, presented $1.97 \%$ of the total above-ground biomass.

\begin{tabular}{|c|c|c|c|c|c|}
\hline \multicolumn{2}{|c|}{ Crown area classes $\left(\mathrm{m}^{2}\right)$} & \multirow{2}{*}{$\mathbf{N}$} & \multicolumn{3}{|c|}{ Individual above-ground biomass (kg) } \\
\hline Interval & Center & & Minimum & Maximum & Mean \\
\hline $26.15-76.15$ & 51.15 & 79.00 & 3.87 & 152.53 & $65.96 \pm 36.7$ \\
\hline $76.15-126.15$ & 101.15 & 136.00 & 163.59 & 873.08 & $432.92 \pm 173.75$ \\
\hline $126.15-176.15$ & 151.15 & 65.00 & 876.50 & 2724.66 & $1514.81 \pm 430.10$ \\
\hline $176.15-226.15$ & 201.15 & 21.00 & 2922.43 & 4697.31 & $3501.01 \pm 342.59$ \\
\hline $226.15-276.15$ & 251.15 & 3.00 & 5584.01 & 6889.49 & $6398.49 \pm 542.89$ \\
\hline 276.15-326.15 & 301.15 & 1.00 & 9058.52 & 9058.52 & 9058.52 \\
\hline General Total & & 305.00 & - & - & $875.69 \pm 811.66$ \\
\hline
\end{tabular}

Table 1. Statistical information from the polygon extraction of the A. angustifolia crowns. 
Comparing the evaluated treatments using the automatic and visual (semi-automatic) crown area evaluation, it is observed that the above-ground biomass estimates were as follows: i) adopting the automatic method, we obtained an above-ground biomass stock of $262.756 \mathrm{~kg}$; and ii) in adopting the automated method with a visual analysis by the interpreter (semi-automatic), we obtained an increase of $1.577 \mathrm{~kg}$, resulting in a final stock of $264.333 \mathrm{~kg}$. It should be noted that even with good results using automatic methods, one must consider the performance of a visual analysis to find details that are sometimes difficult to measure automatically. It is also noticed that new technologies have been improved with the advance in science. The use of data from the ALS is an example that has shown to be promising in the forest area. However, at the same time the adoption of such techniques has revealed new challenges for research.

\section{DISCUSSION}

The application of smoothing filters generated a loss of information, as already verified by Nelson et al. (2002). However, the goal of smoothing was to highlight the tree crowns for better identification and segmentation. The high number of polygons generated by the segmentation process can be related to the classification process itself. According to Sousa et al. (2015), it can be understood as a process in which the image is partitioned into different regions in order to discriminate pixels that have certain characteristics predefined by the user, such as gray levels, textural properties or average values.

The object-oriented classification process, although superior to other processes, usually presents errors due to the excess of polygons. Macedo et al. (2012) delimited tree crowns in clonal forests using objectoriented classification and found an overestimation due to the excess of polygons classified as crowns (commission errors). The study corroborates the results found in this work, since 297 crowns were identified and automatically extracted after filtering (exclusion and adjustment of the polygons) the canopy of the A. angustifolia individuals, representing a correct rate of $88.4 \%$.

The bimodality pattern in the diametric distribution of $A$. angustifolia in natural forests was verified in other studies (Ebling et al., 2013; Orellana et al., 2014), which corroborates this study. The use of two equations to estimate AGB was due to the heterogeneity of crown area values found. The shape of $A$. angustifolia crowns is indicative of its ontogenic stage, with changes as the plant goes through stages of youth, maturity and senescence. Young trees present crowns with a conical shape, while adult and senescent individuals have crowns shaped as a cup or umbel. The primary branches are cylindrical, curved upward, and the lower branches are larger than the upper branches, and both have alternating secondary branches (gypsies) and grouped at the apex (Reitz \& Klein, 1966).

The models developed presented strong coefficient of determination $\left(\mathrm{R}^{2}=0.96\right.$ and 0.98$)$ values, evidencing that the LiDAR technology is a tool with great potential for estimating AGB of A. angustifolia individuals in a native ecosystem. Zolkos et al. (2013) conducted a global review on AGB estimation and found an average $\mathrm{R}^{2}$ of 0.76 for LiDAR studies in different biomes. The authors also highlighted typological variations, with tropical forests having lower values of precision than those of other biomes. Thus, these results agree with those presented in this study.

\section{CONCLUSIONS}

The use of LiDAR data to estimate the aboveground biomass of the individual plants has shown to be promising. It is possible to obtain accurate estimates of the AGB stock with this technology and the methods used. Two equations were necessary to estimate AGB of $A$. angustifolia; one applied to CA up to $183 \mathrm{~m}^{2}$, and another for CA above $183 \mathrm{~m}^{2}$.

The use of LiDAR technology and the methods applied for obtaining information, such as the one developed in this study, enabled measuring the crowns of $A$. angustifolia individuals and estimating AGB. In addition to providing biomass stock estimates with reliability, the use of LiDAR data is an excellent tool for obtaining spatial information.

\section{SUBMISSION STATUS}

Received: 31 Oct., 2017

Accepted: 28 Sept., 2018 


\section{CORRESPONDENCE TO}

\section{Franciel Eduardo Rex}

Universidade Federal do Paraná (UFPR),

Av. Pref. Lothário Meissner, 232, CEP 80210-170,

Curitiba, PR, Brasil

e-mail: francielrexx@hotmail.com

\section{FINANCIAL SUPPORT}

We are thankful to the Conselho Nacional de Desenvolvimento Científico e Tecnológico (CNPq) for the scholarship.

\section{REFERENCES}

Anaya JA, Chuvieco E, Palacios-Orueta A. Aboveground biomass assessment in Colombia: a remote sensing approach. Forest Ecology and Management 2009; 257(4): 1237-1246. 10.1016/j.foreco.2008.11.016

Anderson J, Martin ME, Smith ML, Dubayah RO, Hofton MA, Hyde P et al. The use of waveform lidar to measure northern temperate mixed conifer and deciduous forest structure in New Hampshire. Remote Sensing of Environment 2006; 105(3): 248-261. 10.1016/j. rse.2006.07.001

Chave J, Réjou-Méchain M, Búrquez A, Chidumayo E, Colgan MS, Delitti WBC et al. Improved allometric models to estimate the above-ground biomass of tropical trees. Global Change Biology 2014; 20(10): 3177-3190. 10.1111/gcb.12629

Corona P. Consolidating new paradigms in large-scale monitoring and assessment of forest ecosystems. Environmental Research 2016; 144: 8-14. 10.1016/j.envres.2015.10.017

Dean TJ, Cao QV, Roberts SD, Evans DL. Measuring heights to crown base and crown median with lidar in a mature, even-aged loblolly pine stand. Forest Ecology and Management 2009; 257(1): 126-133. 10.1016/j. foreco.2008.08.024

Drake JB, Knox RG, Dubayah RO, Clark DB, Condit $\mathrm{R}$, Blair JB et al. Above-ground biomass estimation in closed canopy Neotropical forests using LiDAR remote sensing: factors affecting the generality of relationships. Global Ecology and Biogeography 2003; 12(2): 147-159. 10.1046/j.1466-822X.2003.00010.x

Dubayah RO, Knox RG, Hofton MA, Blair JB, Drake JB. Land surface characterization using LiDAR remote sensing. In: Hill M, Aspinall R, editors. Spatial information for land use management. Boca Raton: CRC Press; 2000. p. 25-38.

Ebling AA, Péllico Netto S, Watzlawick LF, Miranda ROV, Abrão SF. Ecologia e projeção diamétrica de três grupos arbóreos em remanescente de Floresta Ombrófila Mista em São Francisco de Paula, RS. Floresta 2013; 43(2): 261 270. 10.5380/rf.v43i2.28604

Food and Agriculture Organization of the United Nations - FAO. Global forest resources assessment 2010: main report. 2010 [cited 2019 May 27]. Available from: https:// bit.ly/1oqbvL6

Freitas SR, Mello MCS, Cruz CBM. Relationships between forest structure and vegetation indices in Atlantic Rainforest. Forest Ecology and Management 2005; 218(13): 353-362. 10.1016/j.foreco.2005.08.036Get

Gao J. Towards accurate determination of surface height using modern geoinformatic methods: possibilities and limitations. Progress in Physical Geography: Earth and Environment 2007; 31(6): 591-605. $10.1177 / 0309133307087084$

Hall FG, Bergen K, Blair JB, Dubayah R, Houghton R, Hurtt $G$ et al. Characterizing 3D vegetation structure from space: mission requirements. Remote Sensing of Environment 2011; 115(11): 2753-2775. 10.1016/j. rse.2011.01.024

He QS, Cao CX, Chen EX, Sun GQ, Ling FL, Pang $Y$ et al. Forest stand biomass estimation using ALOS PALSAR data based on LiDAR-derived prior knowledge in the Qilian Mountain, western China. International Journal of Remote Sensing 2012; 33(3): 710-729. 10.1080/01431161.2011.577829

Houghton RA, Hall F, Goetz SJ. Importance of biomass in the global carbon cycle. Journal of Geophysical Research: Biogeosciences 2009; 114(G2): 1-13. 10.1029/2009JG000935

Hudak AT, Strand EK, Vierling LA, Byrne JC, Eitel JUH, Martinuzzi S et al. Quantifying aboveground forest carbon pools and fluxes from repeat LiDAR surveys. Remote Sensing of Environmente 2012; 123(1): 25-40. 10.1016/j. rse.2012.02.023

Intergovernmental Panel on Climate Change - IPCC. 2006 IPCC guidelines for national greenhouse gas inventories: a primer, prepared by the National Greenhouse Gas Inventories Programme, Eggleston H.S., Miwa K., Srivastava N. and Tanabe K. (eds). Japan: IGES; 2006.

Intergovernmental Panel on Climate Change - IPCC. IPCC Expert Meeting on National Forest GHG Inventories eds: H.S. Eggleston, N. Srivastava, K. Tanabe, J. Baasansuren, National Forest GHG Inventories: a stock taking. Japan: IGES; 2010

Isenburg M. LASTools: award-winning software for LiDAR processing. Version 111216 [software]. 2014 [cited 2017 Mar. 10]. Available from: https://bit.ly/2wp5P0z

Li H, Mausel P, Brondizio E, Deardorff D. A framework for creating and validating a non-linear spectrum-biomass model to estimate the secondary succession biomass in moist tropical forests. ISPRS J. Photogramm. ISPRS 
Journal of Photogrammetry and Remote Sensing 2010; 65(2): 241-254. 10.1016/j.isprsjprs.2010.01.002

Lu DS. The potential and challenge of remote sensing-based biomass estimation. International Journal of Remote Sensing 2006; 27(7): 1297-1328. $10.1080 / 01431160500486732$

Macedo RC, Santos JR, Fonseca LMG, Almeida CM, Soares JV. Delimitação de copas em florestas clonais de Eucalyptus sp. através de classificação baseada em objeto. Revista Técnica do IEP 2012 [cited 2019 May 28]; 2(5): 37-43. Available from: https://bit.ly/2KaOKQ2

Machado SA, Augustynczik ALD, Nascimento RGM, Figura MA, Silva LCR, Miguel EP et al. Distribuição diamétrica de Araucaria angustifolia (Bert.) O. Ktse. em um fragmento de floresta ombrófila mista. Scientia Agraria 2009; 10(2): 103-110. 10.5380/rsa.v10i2.13575

Machado SA, Nascimento RGM, Miguel EP, Téo SJ, Augustynczik ALD. Distribution of total height, transverse area, and individual volume for Araucaria angustifolia (Bert.) O. Kuntze. Cerne 2010; 16(1): 12-21. 10.1590/S0104-77602010000100002

Machado SA, Santos AAP, Zamin NT, Nascimento RGM. Distribuição espacial de um fragmento de Floresta Ombrófila Mista Montana. Ciência Rural 2012; 42(6): 1013-1019. 10.1590/S0103-84782012005000029

Mitri GH, Gitas IZ. A performance evaluation of a burned area object-based classification model when applied to topograhically and non-topographically correct TM imagery. International Journal of Remote Sensing 2004; 25(14): 2863-2870. 10.1080/01431160410001688321

Munroe DK, Nagendra H, Southworth J. Monitoring landscape fragmentation in an inaccessible mountain area: Celaque National Park, Western Honduras. Landscape Urban Plan 2007; 83(2-3): 154-167. 10.1016/j. landurbplan.2007.04.001

Nelson T, Niemann KO, Wulder MA. Spatial statistical techniques for aggregating point objects extracted from high spatial resolution remotely sensed imagery. Journal of Geographical Systems 2002; 4(4): 423-433. 10.1007/ s101090300092

Orellana E, Figueiredo Filho A, Péllico Netto S, Dias AN. Modelagem da distribuição diamétrica de espécies florestais em um fragmento de Floresta Ombrófila Mista. Árvore 2014; 38(2): 297-308. 10.1590/S010067622014000200010

Peel MC. Finlayson BL, McMahon TA. Updated world map of the Köppen-Geiger climate classification. Hydrology and Earth System Sciences 2007; 11: 16331644. 10.5194/hess-11-1633-2007

Popescu SC, Zhao K, Neuenschwander A, Lin C. Satellite LiDAR vs. small footprint airborne LiDAR: comparing the accuracy of aboveground biomass estimates and forest structure metrics at footprint level. Remote Sensing of
Environment 2011; 115(11): 2786-2797. 10.1016/j. rse.2011.01.026

Reitz R, Klein RM. Araucariáceas. In: Reitz R, editor. Flora Ilustrada Catarinense. Itajaí: Herbário Barbosa Rodrigues; 1966. 62p.

Roberts SD, Dean TJ, Evans DL, McCombs JW, Harrington RL, Glass PA. Estimating individual tree leaf area in loblolly pine plantations using LiDAR-derived measurements of height and crown dimensions. Forest Ecology and Management 2005; 213(1-3): 54-70. 10.1016/j. foreco.2005.03.025

Rosenqvist A, Milne A, Lucas R, Imhoff M, Dobson C. A review of remote sensing technology in support of the Kyoto Protocol. Environment Science \& Policy 2003; 6(5): 441-455. 10.1016/S1462-9011(03)00070-4

Sanquetta CR, Corte APD, Jacon AD. Crown area and trunk diameter relationship for tree species at a mixedaraucaria natural forest in the mid-southern Parana State, Brazil. Floresta 2011; 41(1): 63-72. 10.5380/rf.v41i1.21182

Sanquetta CR, Corte APD, Mognon F, Maas GCB, Rodrigues AL. Estimativa de carbono individual para Araucaria angustifolia. Pesquisa Agropecuária Tropical 2014; 44(1): 1-8. 10.1590/S1983-40632014000100006

Schikowski AB, Corte APD, Sanquetta CR. Modelagem do crescimento e de biomassa individual de Pinus. Pesquisa Florestal Brasileira 2013; 33(75): 269-278. 10.4336/2013. pfb.33.75.503

Schoeninger ER, Koehler HS, Watzlawick LF, Oliveira Filho PC. Uso de redes neurais artificiais como uma alternativa para mapeamento de biomassa e carbono orgânico no componente arbóreo de florestas naturais. Ambiência 2009 [cited 2019 May 28]; 4(3): 529-549. Available from: https://bit.ly/2WrWUKj

Silva HF, Ribeiro SC, Botelho AS, Faria RAVB, Teixeira MBR, Mello JM. Estimativa do estoque de carbono por métodos indiretos em área de restauração florestal em Minas Gerais. Scientia Forestalis 2015; 43(108): 943-953. $10.18671 /$ scifor.v43n108.18

Silveira P. Estimativa da biomassa e carbono acima do solo em um fragmento de floresta ombrófila densa utilizando o método da derivação do volume comercial. Floresta 2010; 40(4): 789-800. 10.5380/rf.v40i4.20330

Soenen SA, Peddle DR, Hall RJ, Coburn CA, Hall FG. Estimating aboveground forest biomass from canopy reflectance model inversion in mountainous terrain. Remote Sensing of Environment 2010; 114(7): 1325-1337. 10.1016/j.rse.2009.12.012

Solomon S, Qin D, Manning M, Chen Z, Marquis M, Averyt K, Tignor MMB, Miller HL, editors. Climate change 2007: the physical science basis. Cambridge: Cambridge University Press; 2007.

Sousa DG, Mincato RL, Kawakubo FS. Análise multitemporal do uso da terra utilizando imagens 
Landsat-5 TM da região de Alfenas, Sul de Minas Gerais, visando a conservação de fragmentos florestais. Revista Brasileira de Geografia Física 2015 [cited 2019 May 27]; 08(5): 1482-1492. Available from: https://bit.ly/2QsLv7K

Southworth J, Tucker C. The influence of accessibility, local institutions, and socioeconomic factors on forest cover change in the mountains of western Honduras. Mountain Research and Development 2001; 21(3): 276283. 10.1659/0276-4741(2001)021\%5B0276:TIOALI\%5 D2.0.CO;2

Suárez JC, Ontiveros C, Smith S, Snape S. Use of airborne LiDAR and aerial photography in the estimation of individual tree heights in forestry. Computers \& Geosciences 2005; 31(2): 253-262. 10.1016/j.cageo.2004.09.015

Sun G, Ranson KJ, Kharuk VI. Radiometric slope correction for forest biomass estimation from SAR data in the Western Sayani Mountains, Siberia. Remote Sensing of Environment 2002; 79(2-3): 279-287. 10.1016/S0034-4257(01)00279-6

Tangki H, Chappell NA. Biomass variation across selectively logged forest within a $225-\mathrm{km}^{2}$ region of
Borneo and its prediction by Landsat TM. Forest Ecology and Management 2008; 256(11): 1960-1970. 10.1016/j. foreco.2008.07.018

Teixeira AMG, Soares-Filho BS, Freitas SR, Metzger JP. Modeling landscape dynamics in an Atlantic Rainforest region: implications for conservation. Forest Ecology and Management 2009; 257(4): 1219-1230. 10.1016/j. foreco.2008.10.011

Turner W, Spector S, Gardiner N, Fladeland M, Sterling E, Steininger M. (2003). Remote sensing for biodiversity science and conservation. Trends in Ecology \& Evolution 2003; 18(6): 306-314. 10.1016/S0169-5347(03)00070-3

Watzlawick LF. Estimativa de biomassa e carbono em floresta ombrófila mista e plantações florestais a partir de dados de imagens do satélite IKONOS II [tese]. Curitiba: Universidade Federal do Paraná; 2003.

Zolkos SG, Goetz SJ, Dubayah R. A meta-analysis of terrestrial aboveground biomass estimation using lidar remote sensing. Remote Sensing of Environment 2013; 128: 289-298. 10.1016/j.rse.2012.10.017 